\title{
Photoprotective activity of geopropolis produced by Melipona subnitida (Apidae, Meliponinae) in the semiarid of the Brazilian Northeast
}

\author{
Atividade fotoprotetora de geoprópolis produzida por Melipona subnitida (Apidae, Meliponinae) no \\ semiárido do Nordeste brasileiro
}

Actividad fotoprotectora de geopropóleos producidos por Melipona subnitida (Apidae, Meliponinae) en el semiárido del Nordeste brasileño

Jael Soares Batista

ORCID: https://orcid.org/0000-0001-9663-7468 Federal Rural Semi-Arid University, Brazil E-mail: Jaelsoares@hotmail.com

Antonio Salatino ORCID: https://orcid.org/0000-0003-4538-8005 University of São Paulo, Brazil E-mail: asalatino@ib.usp.br

Giuseppina Negri ORCID: https://orcid.org/0000-0002-4858-6632 University of São Paulo, Brazil E-mail: gnegri@terra.com.br

Carmen Eusebia P. Jara ORCID: https://orcid.org/0000-0001-6832-1730 University of São Paulo, Brazil

E-mail: carmenpalacios12@hotmail.com

Kaliane Alessandra R. de Paiva ORCID: https://orcid.org/0000-0002-0341-1484 Federal Rural Semi-Arid University, Brazil E-mail: kalianepaiva@yahoo.com.br

Wanderson Lucas Alves dos Santos ORCID: https://orcid.org/0000-0002-6583-0481

Federal Rural Semi-Arid University, Brazil

E-mail: wanderson.santos@alunos.ufersa.edu.br

Tiago Da Silva Teófilo

ORCID: https://orcid.org/0000-0002-3021-0880

Federal Rural Semi-Arid University, Brazil E-mail: tiago.teofilo@ufersa.edu.br

Natanael Silva Félix

ORCID: https://orcid.org/0000-0002-9631-2847

Federal Rural Semi-Arid University, Brazil E-mail: natann-013@ hotmail.com

Francisco Herbeson Aquino Silva

ORCID: https://orcid.org/0000-0002-9653-5442

Federal Rural Semi-Arid University, Brazil E-mail: herbeson2706@hotmail.com

Victor Hugo V. Rodrigues

ORCID: https://orcid.org/0000-0003-2974-8015

Maurício de Nassau University Center, Brazil E-mail: victorvieira81@gmail.com

\begin{abstract}
Although geopropolis has been the subject of many chemical and pharmacological studies, there are few studies investigating the photoprotective activity of formulations containing propolis. Thus, we investigated in vivo the photoprotective efficacy of the cream containing geopropolis extract by macroscopic and histological evaluation of the skin of Wistar rats subjected to ultraviolet radiation (UVB). We also evaluated the chemical composition of hydroethanolic extract using the HPLC-DADESI-MS/MS technique, as well as antioxidant activity by the photocolorimetric method of free radical DPPH (2.2-diphenyl-1-picrylhydrazine) and cytotoxic activity by the in vitro MTT quantitative method [brometo de 3- (4.5dimetiltiazol-2-il)-2.5-difeniltetrazolio]. The extract had a varied chemical composition, 29 different phenolic compounds being detected, distributed between phenols and flavonoids,
\end{abstract}


the latter being represented by chalcones, flavones and flavonols. The highest percentages of DPPH inhibition e o baixo valor de IC50 indicaram que o extrato apresentou alta atividade antioxidante. The hydroethanolic extract did not exert cytotoxic effects since high percentages of viability of L929 fibroblasts were observed after incubation for 72 hours at different concentrations of the extract. On skin submitted to cream application containing of geopropolis extract and the irradiation with UVB did not occur macroscopic and histological lesions. Thus, we concluded that the cream containing of geopropolis extract produced by Melipona subnitida was able to protect the skin from lesions induced by UVB irradiation, thus demonstrating photoprotective effect.

Keywords: Meliponinae; Geopropolis; Photoprotective effect; Phenol contents; Antioxidant action; Sun protection factor.

\section{Resumo}

Embora a geoprópolis tenha sido objeto de muitos estudos químicos e farmacológicos, poucos são os estudos que investigam a atividade fotoprotetora de formulações contendo própolis. Assim, investigamos in vivo a eficácia fotoprotetora do creme contendo extrato de geoprópolis por meio da avaliação macroscópica e histológica da pele de ratos Wistar submetidos à radiação ultravioleta (UVB). Também avaliamos a composição química do extrato hidroetanólico pela técnica de HPLC-DADESI-MS / MS, bem como a atividade antioxidante pelo método fotocolorimétrico do radical livre DPPH (2,2-difenil-1-picrilhidrazina) e a atividade citotóxica pelo MTT in vitro método quantitativo [brometo de 3- (4,5dimetiltiazol-2-il) -2,5-difeniltetrazólio]. O extrato apresentou composição química variada, sendo detectados 29 compostos fenólicos diferentes, distribuídos entre fenóis e flavonóides, sendo estes últimos representados por chalconas, flavonas e flavonóis. Os maiores percentuais de inibição do DPPH e o baixo valor de IC50 indicaram que o extrato apresenta alta atividade antioxidante. $\mathrm{O}$ extrato hidroetanólico não exerceu efeito citotóxico, pois altas porcentagens de viabilidade de fibroblastos L929 foram observadas após incubação por 72 horas em diferentes concentrações do extrato. Na pele submetida à aplicação de creme contendo extrato de geoprópolis e à irradiação com UVB não ocorreram lesões macroscópicas e histológicas. Assim, concluímos que o creme contendo extrato de geoprópolis produzido por Melipona subnitida foi capaz de proteger a pele das lesões induzidas pela irradiação UVB, demonstrando, assim, efeito fotoprotetor.

Palavras-chave: Meliponinae; Geoprópolis; Efeito fotoprotetor; Teor de fenol; Ação antioxidante; Fator de proteção solar.

\section{Resumen}

Aunque el geopropóleo ha sido objeto de muchos estudios químicos y farmacológicos, existen pocos estudios que investiguen la actividad fotoprotectora de formulaciones que contienen propóleos. Así, investigamos in vivo la eficacia fotoprotectora de la crema que contiene extracto de geopropóleo mediante evaluación macroscópica e histológica de la piel de ratas Wistar sometidas a radiación ultravioleta (UVB). También evaluamos la composición química del extracto hidroetanólico mediante la técnica HPLC-DADESI-MS / MS, así como la actividad antioxidante por el método fotocolorimétrico del radical libre DPPH (2.2-difenil-1-picrilhidrazina) y la actividad citotóxica por el MTT in vitro método cuantitativo [brometo de 3- (4,5-dimetiltiazol-2-il) -2,5-difeniltetrazolio]. El extracto tuvo una composición química variada, detectándose 29 compuestos fenólicos diferentes, distribuidos entre fenoles y flavonoides, estos últimos representados por chalconas, flavonas y flavonoles. Los porcentajes más altos de inhibición de DPPH e o baixo valor de IC50 indicaram que o extrato apresentou alta atividade antioxidante. El extracto hidroetanólico no ejerció efectos citotóxicos ya que se observaron altos porcentajes de viabilidad de los fibroblastos L929 después de la incubación durante 72 horas a diferentes concentraciones del extracto. Sobre la piel sometida a la aplicación de una crema que contenía extracto de geopropóleo y la irradiación con UVB no se produjeron lesiones macroscópicas e histológicas. Así, concluimos que la crema que contiene extracto de geopropóleo producida por Melipona subnitida fue capaz de proteger la piel de las lesiones inducidas por la irradiación UVB, demostrando así un efecto fotoprotector.

Palabras clave: Meliponinae; Geopropolis; Efecto fotoprotector; Contenido de fenol; Acción antioxidante; Factor de protección solar.

\section{Introduction}

Brazil is geographically located in a position that provides the highest intensity of solar radiation, where the radiation that penetrates deep into the skin, reaching the dermal layer which is directly related to skin lesions and the high incidence of skin cancer such as carcinoma and melanoma (Baillo \& Lima, 2012; Cabral et al., 2011). In the epidermis and dermis, UVB rays promote photochemical reactions and secondary interactions that generate free radicals capable of promoting oxidative stress and consequently damage to DNA, proteins and cell membrane (Arimon et al., 2015; Romanhole et al., 2016).

Given this, in recent decades, compounds derived from natural sources have gained considerable attention for use of 
cosmetics, since show protective effects and less toxicity. This increases the importance of studying a wide selection of active molecules in sunscreen formulations (Saewan \& Jimtaisong, 2013). Recent photoprotection strategies have included incorporating natural antioxidant and anti-inflammatory compounds into sunscreens (Almeida et al., 2019).

By definition, propolis is a natural substance produced by bees consisting of resins, balsams, waxes, essential oils, pollen grains. Bees of the genus Melipona also add soil to the mixture, forming the geopropolis (Carvalho-Zilse \& Silva, 2012). Propolis e geopropolis are used in the popular tradition of northeastern Brazil as a natural medicine (Silva et al., 2016). Propolis and geopropolis has aroused a growing interest among researchers and many studies have been conducted on its chemical composition and pharmacological activities. Thus, research has confirmed several biological activities such as antimicrobial, anti-inflammatory, antioxidant, hepatoprotective, antitumor and healing activities, and the effectiveness in the treatment of burns, wounds and ulcers, among others, have been reported in scientific article (Afrouzan et al., 2018; Cardinault et al., 2012; Castro \& Salgueiro, 2016; Pontes et al., 2018; Kunrath et al., 2017).

Although an increasing number of studies with propolis have been observed, there are still few critical reviews on the use of propolis products in the clinical context (Sforcin \& Bankova, 2011). In this context, it was emphasized that propolis is still little explored as a photoprotector, although its use offers so many benefits (Karapetsas et al., 2019). The finding that propolis is capable of protecting the skin from ultraviolet radiation (UVB) may contribute to validate its use in topical formulations such as organic sunscreens with the ability to protect the skin against damage caused by solar radiation. Thus, this study aimed to evaluate in vivo the photoprotective efficacy of the cream containing geopropolis extract produced by Melipona subnitida through the macroscopic and histological evaluation of the skin of Wistar rats submitted to UVB ultraviolet radiation.

\section{Material and Methods}

\subsection{Samples and extraction}

The geopropolis sample produced by the bee Melipona subnitida was collected from apiaries in the city of Mossoró, Rio Grande do Norte, located at 37²0'39" west latitude and $05^{\circ} 11^{\prime} 15^{\prime \prime}$ south longitude. The climate of the region is warm semi-arid tropical type, with annual average temperature of $27^{\circ} \mathrm{C}$, relative temperature of $50 \%$ and annual average of $500 \mathrm{~mm}$.

To obtain the extract, 100g of raw geopropolis was crushed in a Walita $500 \mathrm{~W}$ blender and transferred to a flat bottom balloon. Ethyl alcohol was added, in the proportion of 5:1 (Ethanol/Water) (v/v), at room temperature (Garcia et al., 2004). The extract obtained was then submitted to rotoevaporation at a temperature of $40{ }^{\circ} \mathrm{C}$ to remove the ethanol and obtain the concentrated extract. The concentrated extract was then submitted to drying in a forced ventilation oven at a temperature of 50 ${ }^{\circ} \mathrm{C}$.

\subsection{Analysis of the chemical composition}

The constituents of the hydroethanolic extract of geopropolis (HEG) were characterized by the HPLC-DAD-ESIMS/MS technique. The equipment used was a DADSPD-M10AVP chromatograph (Shimadzu Corp., Kyoto, Japan), which was coupled to an Esquire 3000 Plus mass spectrometer (Bruker Daltonics, Billerica, MA, USA), and equipped with a quadrupole ion trap mass analyzer (Hatami et al., 2014). The column temperature was maintained at $45^{\circ} \mathrm{C}$ nd the flow rate was $1 \mathrm{~mL} / \mathrm{min}$. The DAD acquisition wavelength was set in the range of $240-400 \mathrm{~nm}$ and chromatograms were recorded at 280 and $330 \mathrm{~nm}$. The mobile phase was composed by eluent A $(0.1 \%$ aqueous acetic acid) and eluent B (methanol). The following elution program, based on concentrations of the B solvent, was used: $0-8.0 \mathrm{~min}: 0 \%-50 \%$; 8.0-8.1 min: 51\%; 8.1-15.0 min: 51\% B; 15.0-15.1 min: 51\%-52\%; 15.1-23.0 min: 52\%; 23-23.1 min: 52\%-53\%; 23.1-31.0 min: 53\%; 31.0-31.1 min: 53\%54\%; 31.1-35.0 min: 54\%-60\%; 35.0-45.0 min: 60\%-100\%; 45.0-55.0 min: 100\%. Nebulization was aided with a coaxial 
nitrogen sheath gas provided at pressure of 27 psi. Mass spectra were acquired in both negative and positive modes with ion spray voltage at $3.0 \mathrm{kV}$, capillary temperature at $300{ }^{\circ} \mathrm{C}$, capillary voltage at $4500 \mathrm{~V}$ and drying gas flow $12 \mathrm{~L} / \mathrm{min}$. The constituents were characterized by ultraviolet and mass spectral (MS) data, which were compared with mass spectral databases Phenol-Explorer (www.phenol-explorer.eu), ChemSpider (http://www.chemspider.com), Metlin (http://metlin.scripps.edu) and HMDB (www.hmdb.ca), besides MS data reported in the literature (Kranjc et al., 2016; Silva et al., 2019). Identification of chrysoeriol, kaempferol, quercetin, myricetin, rhamnetin, isorhamnetin was also obtained by comparison of MS spectra and retention times with authentic samples.

\subsection{Evaluation of antioxidant activity by the DPPH method}

For the evaluation of antioxidant activity, the in vitro photocolorimetric method of free radical DPPH (2,2-diphenyl-1picrylhydrazine) (Mensor et al., 2001). For analysis, the HEG at $1 \mathrm{mg} / \mathrm{mL}$ concentration was gradually diluted in methanol, resulting in different concentrations $(1 ; 0.8 ; 0.6 ; 0.4 ; 0.2$ e $0.1 \mathrm{mg} / \mathrm{mL}) .1 \mathrm{~mL}$ of each concentration was placed in test tubes along with $1.5 \mathrm{~mL}$ of a $60 \mu \mathrm{mol} . \mathrm{L}^{-1}$ DPPH methanolic solution. After 15 minutes for the absorbance of the samples in a spectrophotometer with a wavelength of $517 \mathrm{~nm}$, with methanol as white only. The inhibition percentage for each concentration of HEG solution was obtained from the ratio of its absorption to the absorbance of a solution containing $1 \mathrm{~mL}$ methanol and $1.5 \mathrm{~mL}$ DPPH solution. All readings were performed in triplicate, and the percentage of antioxidant activity of the extracts was calculated, using the formula: $\mathrm{AA}=100-[(\mathrm{Aa}-\mathrm{Ab}) \mathrm{x} 100] / \mathrm{Ac}$, where: \%AA = percentage of antioxidant activity; $\mathrm{Aa}=$ absorbance of the sample; $\mathrm{Ab}=$ absorbance of the white; $\mathrm{Ac}=$ absorbance of the control.

The standard DPPH curve was constructed by plotting the mean value of the absorbances obtained by the solution concentrations. After obtaining the percentage values of free radical inhibition, they were analyzed using Oringin Software 7.0 in order to obtain a graph showing values by which the $50 \%$ inhibitory concentration of DPPH radical (IC50) would be calculated the sample concentration required to consume $50 \%$ of the DPPH.

The mean absorbance data obtained from the test solution, positive control and negative control were compared by analysis of variance ANOVA, followed by Tukey's post-test using the GraphPad Prism software version 5.0 (GraphPad Software, San Diego, CA, USA), with a significance level of $\mathrm{P}<0.05$.

\subsection{Cytotoxic activity}

The in vitro cytotoxic activity of HEG was evaluated by the Metiltetrazolium (MTT) colorimetric method according to the methodology proposed by Mosmann (1983). In this study, human connective tissue and human keratinocyte cell lines (HaCaT) were used. These strains were seeded in 96 well and exposed wells for 72 hours to different concentrations of the HEG $(500 ; 250 ; 125 ; 62.5 ; 31.2 ; 15.6$ and $781 \mu \mathrm{g} / \mathrm{mL}$ ) and the cytotoxic substance dimethylsulfoxide (DMSO), used as a negative control.

Subsequently, $10 \mu \mathrm{L}$ of MTT reagent at $5 \mathrm{mg} \cdot \mathrm{mL}^{-1}$ was added to all wells of the plate, and the plate was incubated for 4 hours at $37{ }^{\circ} \mathrm{C}$ in a humidified greenhouse in a $5 \% \mathrm{CO}_{2}$ atmosphere. For the quantification of the salt reduced to formazan by living cells, the absorbances of the resulting solutions were measured with the aid of a plate spectrophotometer at a wavelength of $570 \mathrm{~nm}$. The mean absorbance data obtained from the test solution and negative control were compared by analysis of variance ANOVA, followed by Tukey's post-test using the GraphPad Prism software version 5.0 (GraphPad Software, San Diego, CA, USA), with a significance level of $\mathrm{P}<0.05$.

\subsection{Formulation of the cream containing geopropolis extract}

The dry extract of the geopropolis was solubilized in deionized water and propylene glycol at $2.5 \%, 5.0 \%, 10 \%$ and 
submitted to evaluation by the in vitro spectrophotometric method developed by Mansur et al. (1986) for preliminary determination of SPF. Thus, the dry extract in different dilution percentages was subjected to reading, at wavelengths that comprise $290 \mathrm{~nm}$ to $320 \mathrm{~nm}$. With that, it was possible to verify the percentage of dilution of the extract of most interest with regard to absorption in the ultraviolet region. Thus, in the formulation of the cream, the $10 \%$ extract was incorporated since, among the three dilution percentages, the $10 \%$ extract showed superior results in the preliminary determination of the SPF.

The photoprotective formulation was made from a base cream containing the oily phase (lanette $\mathrm{N} 7 \%$, liquid vaseline $5 \%$ ) and the aqueous phase (extract of the geopropolis a 10\%, glycerine 5\%, nipagin 0.1\%, distilled water qs.p. 100g). The photoprotective formulation was developed by the traditional preparation process, with the aqueous and oily phases heated separately $\left(70-75^{\circ} \mathrm{C}\right)$, and then the aqueous phase was slowly poured under the oily phase, under manual agitation at a temperature of $25^{\circ} \mathrm{C}$.

\subsection{In vitro sun protection factor (SPF)}

The in vitro SPF of the cream containing geopropolis extract and the base cream without the addition of geopropolis was determined (Mansur et al., 1986). For this, the cream was diluted in absolute ethanol at a concentration of $0.2 \mathrm{mg} / \mathrm{mL}$. These solutions were then subjected to spectrophotometer reading to determine absorbances in the wavelength range from 290 to $320 \mathrm{~nm}$. For the calculation of SPF, was used the mathematical expression that relates the erythematogenic effect and the light intensity of each wavelength (EE x I).

For the calculation of SPF, the formula was applied:

At where:

$\mathrm{CF}=$ correction factor $(10)$;

EE $(\kappa)=$ erimatogenic effect of radiation at each wavelength $\kappa$;

$\mathrm{I}(\Lambda)=$ intensity of solar radiation at each $\Lambda$;

Abs $=$ Absorbance at each $\Lambda$.

\subsection{Photoprotective activity in vivo}

24 Wistar rats (Rattus norvegicus var. alba), weighing approximately $200 \mathrm{~g}$, were used. During the experimental period, all animals were kept in the biotery, housed in polypropylene boxes ( 2 animals per box), lined with shavings, under temperature control $\left(2{ }^{\circ} \mathrm{C}\right.$ to $\left.23{ }^{\circ} \mathrm{C}\right), 12$ hours light and 12 hours dark photoperiod. Commercial feed (Purina $\left.{ }^{\circledR}\right)$ and water $a d$ libitum. According to the manufacturer, the feed has $23 \%$ crude protein, $4 \%$ total lipids, $5 \%$ fiber and $12 \%$ minerals. The experimental protocol was submitted to the Animal Use Ethics Committee (CEUA) of the State University of Rio Grande do Norte (UERN), with protocol number 004/18.

The rats were randomly assigned to four experimental groups, containing six animals in each: group G1 in which the skin does not receive cream and was not subject to UVB irradiation; Group G2 whose skin was subjected to UVB radiation; group G3, whose skin has been subjected to the cream containing geopropolis and subjected to UVB irradiation and the group G4 in which the skin was submitted to the application of the base cream without that of geopropolis and were irradiated with UVB. 


\subsection{Irradiation of rat skin}

Animals were anesthetized with dissociative anesthesia using xylazine hydrochloride $(8.0 \mathrm{mg} / \mathrm{Kg})$ and ketamine hydrochloride $(140 \mathrm{mg} / \mathrm{Kg})$ administered intraperitoneally. After anesthesia, a trichotomy was performed on the dorsolumbar region skin, with the aid of a knit blade, making a square area of $25 \mathrm{~cm}^{2}$. One hour before the beginning of the irradiation, on the trichotomized back of the G3 animals, $0.5 \mathrm{~g}$ of the geopropolis cream was applied topically (Figueiredo et al., 2014). The cream was applied with the aid of sterile and individual wood spatulas, forming a film containing $2.0 \mathrm{mg} / \mathrm{cm}^{2}$, which covered the entire surface of the trichotomized skin.

The UVB irradiation model was performed (Batista et al., 2018). In this model, the skin irradiation of the rats was performed using a UVB ultraviolet lamp, model Osram ULTRA-VITALUX, which emits radiation in the range of 280-315 $\mathrm{nm}$, emitting UV that mimicked tropical sun. The lamp was located at a distance of $20 \mathrm{~cm}$ above the area to be irradiated. Upon reaching the anesthetic plane, the animals were positioned supine on a wooden board and their dorsal regions were directly exposed to UVB radiation for a period of 1 hour.

\subsection{Macroscopic examination}

Six hours after the end of irradiation, the animals were euthanized by cervical dislocation under deep anesthesia. The dorsal region of each animal was evaluated macroscopically, through visual evaluation, in order to identify possible alterations, considering the presence of blisters, coloration, brightness, opacity of the skin, besides softness and hydration. The intensity of these changes was classified as absent $(0)$, discrete $(+)$, moderate $(++)$ and intense (+++).

\section{Histological Examination}

The skin area of the dorsal region of each animal was impacted with scalpel blade n. 15, divulsed and separated from the subcutaneous tissue with scissors with the aid of a dissecting forceps. Afterwards, skin fragments were fixed in $10 \%$ formaldehyde buffered solution and routinely processed for histology, embedded in paraffin, cut to $5 \mu$ thick, stained with hematoxylin-eosin (HE), by Masson's trichrome for evaluation of collagen fibers and Toluidine Blue for mast cell evaluation. Descriptive histological analysis of the skin alterations was then performed, and the following histological parameters were evaluated: presence of inflammatory cells, mast cells, necrotic cells and collagen fibers. These histological parameters were grouped as absent, mild, moderate or intense (Akkol et al., 2008).

\section{Results}

\subsection{Chemical composition}

The evaluation using the HPLC-DAD-ESI-MS/MS technique demonstrated the geopropole produced by Melipone subnitida, had a varied chemical composition, being detected 29 phenolic compounds, distributed between flavonoids and phenols. In the group of flavonoids it was possible to identify chalcones $(1,6,10,20,21$ and 23), flavones $(8,9,11,13,16$ and 17) and flavonols $(2,3,4,5,7,12,14,15,18,19,22$ and 26). Finally, in the group of phenols the compounds $24,25,27,28$ and 29 were identified. The analyses showed that there were differences in the relative abundance of the extract constituents, with the compounds identified by the numbers $20,21,22,23,24,25,26,17,28$ and 29 showing longer retention time of the peaks (Table 1). 
Table 1. Constituents of hydroethanolic extracts of geopropolis Melipona subnitida (Meliponinae, Apidae) in the semiarid of the Brazilian Northeast analysed by HPLC-DAD-ESI-MS/MS.

\begin{tabular}{|c|c|c|c|}
\hline $\mathbf{N}^{\mathbf{0}}$ & Rt (min) & UV/vis (nm) & Characterization proposed \\
\hline 1 & 11.3 & 260,375 & $4,2^{\prime}, 4^{\prime}$-trihydroxy chalcone - isoliquiritigenin \\
\hline 2 & 12.6 & 255,360 & Quercetin \\
\hline 3 & 13.8 & 255,360 & Isorhamnetin - (3'-methoxyquercetin) \\
\hline 4 & 14.5 & 255,360 & kaempferol \\
\hline 5 & 15.1 & 255,360 & 4'-O-methyl kaempferol - Kaempferide \\
\hline 6 & 15.7 & 370 & 4,5',6'-trihydroxy-2',4'-dimethoxy chalcone \\
\hline 7 & 16.0 & $260-360$ & Rhamnetin (7-O-methylquercetin) \\
\hline 8 & 16.4 & $270-340$ & Apigenin \\
\hline 9 & 16.6 & $270-340$ & 5,7,4'-trihydroxy-3'-methoxyflavone \\
\hline 10 & 18.2 & ND & Mandelic acid acetyl glucoside \\
\hline 11 & 19.0 & $270-340$ & Cirsiliol (5,3',4'-trihydroxy-6,7-dimethoxyflavone) \\
\hline 12 & 19.9 & $260-360$ & Myricetin 3,7,3'-trimethyl ether; \\
\hline 13 & 21.1 & $270-345$ & Cirsimaritin \\
\hline 14 & 21.9 & $260-360$ & Quercetin dimethyl ether \\
\hline 15 & 22.4 & $260-360$ & Kaempferol dimethyl ether \\
\hline 16 & 27.0 & 290 & Naringenin \\
\hline 17 & 29.0 & $260-360$ & 3-O-methyl galangin or 5,7-dihydroxy-3-methoxy \\
\hline
\end{tabular}

flavone

\begin{tabular}{llll}
\hline $\mathbf{1 8}$ & 29.6 & $260-360$ & Kaempferol dimethyl ether isomer \\
\hline $\mathbf{1 9}$ & 29.7 & $260-360$ & Kaempferol dimethyl ether isomer \\
\hline $\mathbf{2 0}$ & 30.0 & $245-360$ & $2^{\prime}, 4^{\prime}$-dihydroxy-4-methoxychalcone \\
\hline $\mathbf{2 1}$ & 30.5 & 370 & 4'-methoxy-2',6',4- trihydroxy chalcone $^{\prime}$ \\
\hline $\mathbf{2 2}$ & 32.5 & $260-360$ & Quercetin 3,7,3 -trimethyl ether \\
\hline $\mathbf{2 3}$ & 38.5 & ND & Mandelic acid acetyl rhamnoside \\
\hline $\mathbf{2 4}$ & 39.8 & ND & 4-demethyldeoxypodophyllotoxin \\
\hline $\mathbf{2 5}$ & 40.3 & ND & glucopyranoside \\
\hline $\mathbf{2 6}$ & 42.1 & $330-350$ & K-methoxy-3-prenyl benzoic acid acetylglucoside \\
\hline $\mathbf{2 7}$ & 43.4 & ND & 4-methoxy-3-prenyl benzoic acid acetylrhamnoside \\
\hline $\mathbf{2 8}$ & 47.2 & 330 & 4-O-vinyl-3,5-diprenyl coumaric acid \\
\hline $\mathbf{2 9}$ & 48.3 & 330 & 4-O-ethoxy-3,5-diprenyl coumaric acid
\end{tabular}

Source: Authors.

\subsection{Antioxidant activity}

The results obtained in the DPPH free radical sequestration capacity test are presented in Figure 1, which shows that the graph representing antioxidant percentage showed a linear pattern, ie, the higher the concentration of HEG, the higher the consumption. DPPH and higher was the antioxidant activity. Thus, the highest percentages of DPPH inhibition occurred at 
concentrations of $1 \mathrm{mg} / \mathrm{mL}$ and $0.8 \mathrm{mg} / \mathrm{mL}$, which were respectively $85.0 \%$ and $78.5 .85 \%$. The inhibitory concentration required to decrease the free radical DPPH (IC50) by $50 \%$ was $48.0 \mu \mathrm{g} / \mathrm{mL}$.

Figure 1. Antioxidant activity (\%) as a function of the concentration of the HEG, analyzed by the DPPH method.

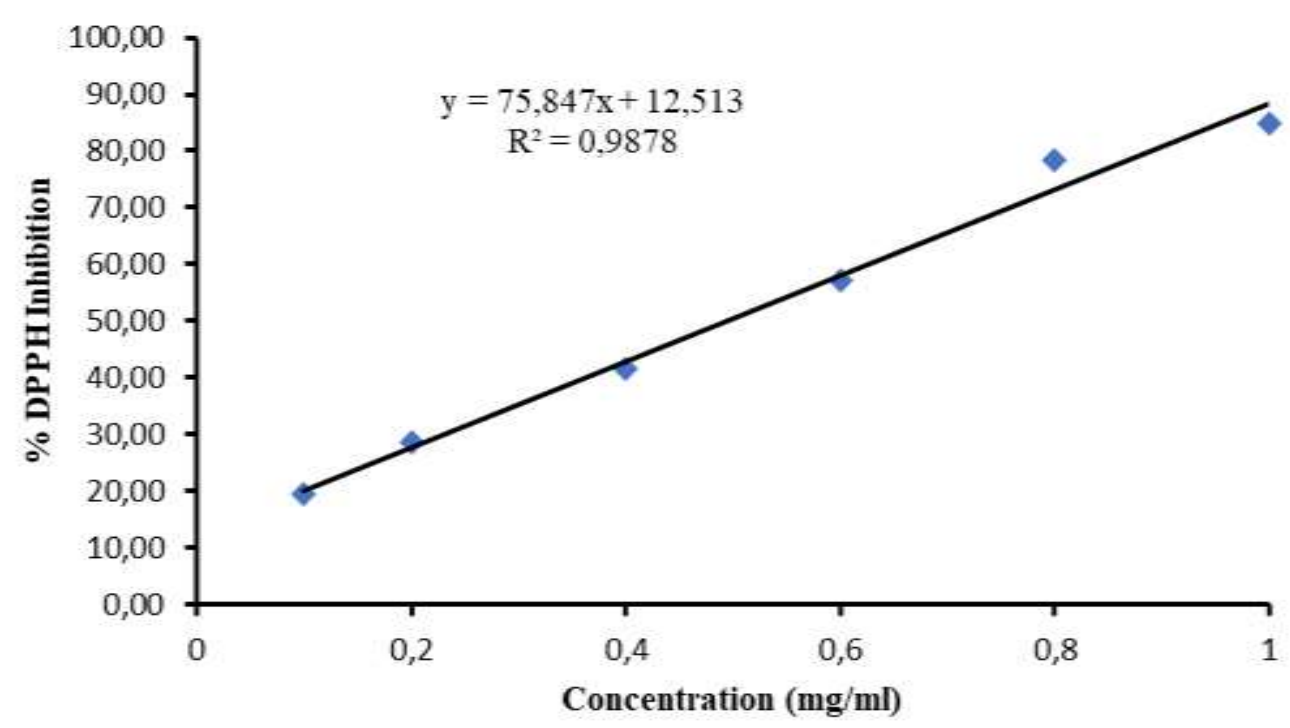

Source: Authors.

\subsection{Cytotoxic activity:}

From the analysis of the mean absorbances, it can be inferred that the viability percentages of L929 and keratinocyte $\mathrm{HaCaT}$ fibroblasts were dependent on the concentration of HEG. According to Figure 2, there was a significant reduction in cell viability of the two cell lines tested at concentrations of $5.0 \mu \mathrm{g} / \mathrm{mL}$ and $2.5 \mu \mathrm{g} / \mathrm{mL}$ compared to the negative control viability value. From the concentration of $1.25 \mu \mathrm{g} / \mathrm{mL}$ there was a significant increase in the viability of the cell lines, so that there was no significant difference in the percentages of viability of the negative control (DMSO). 
Figure 2. Viability of fibroblasts (L929) and keratinocytes (HaCaT) analyzed by colorimetric assay using MTT (tetrazolium salt) after $72 \mathrm{~h}$ exposure to different concentrations of HEG. Mean values followed by different lowercase letters on the column indicate a significant difference $(\mathrm{p}<0.05)$.

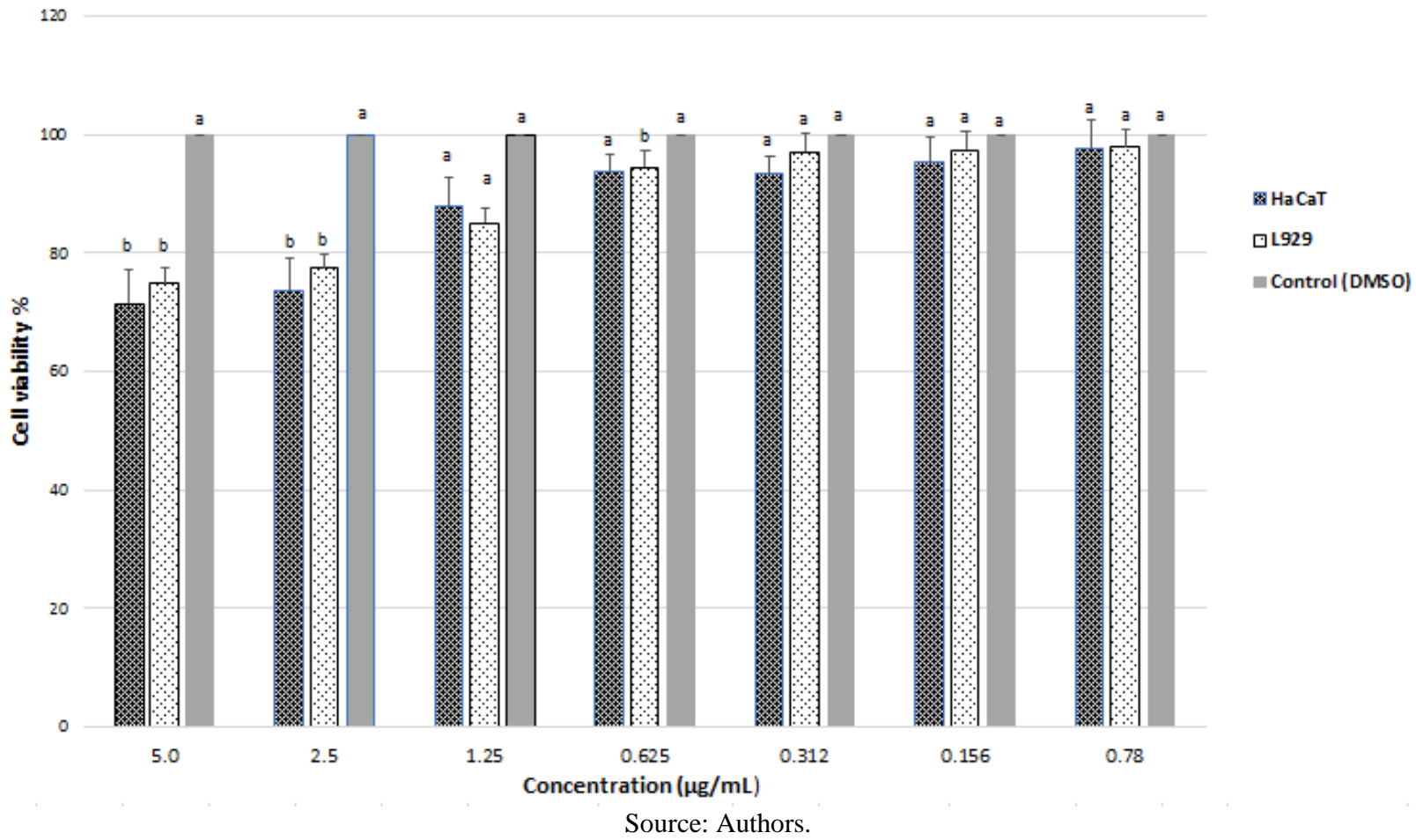

\subsection{Photoprotective activity in vivo}

The result of the analysis of the in vitro sun protection factor evaluation (Mansur et al., 1986) showed that the base cream and the cream containing the geopropolis extract had SPF values of 8,32 $\pm 1,08$ and 20,13 $\pm 1,27$, respectively.

\subsection{Photoprotective activity}

A macroscopic evaluation showed that the skin of the animals of groups G1 and G3 has a normal morphological appearance, without changes in appearance, color and consistency. While all G2 animals had cutaneous lesions characterized by the presence of focal areas of burn and erythema, dehydrated skin with rough and rough surface. The animals belonging to G4 had the same characteristics observed in G2, but the alterations were less intense (Figure 3). A histological analysis showed that the skin of animals belonging to G1 and G3 is not altered, presenting normal histological appearance. G2 animal skin shows keratinocyte necrosis, moderate amount of polymorphonuclear inflammatory cells, mast cells, vascular congestion, interstitial edema, and collagen fiber dissociation. Similar to the macroscopic evaluation of the skin, the G4 animals presented the same histological lesions found in the G2 skin, but the changes were less intense (Figure 4). 
Figure 3. Macroscopic appearance of the skin of Rattus norvegicus var. alba, Wistar strain, in the experimental groups. G1 Skin not treated with photoprotective cream and not subjected to UVB irradiation; G2 - skin subjected to UVB irradiation; G3 - skin subjected to the cream containing geopropolis and subjected to UVB irradiation; G4 - skin was submitted to the application of the base cream without geopropolis and irradiated with UVB. Note in G1 and G3 normal looking skin. In G2 and G4 skin with focal areas of sunburn and erythema.
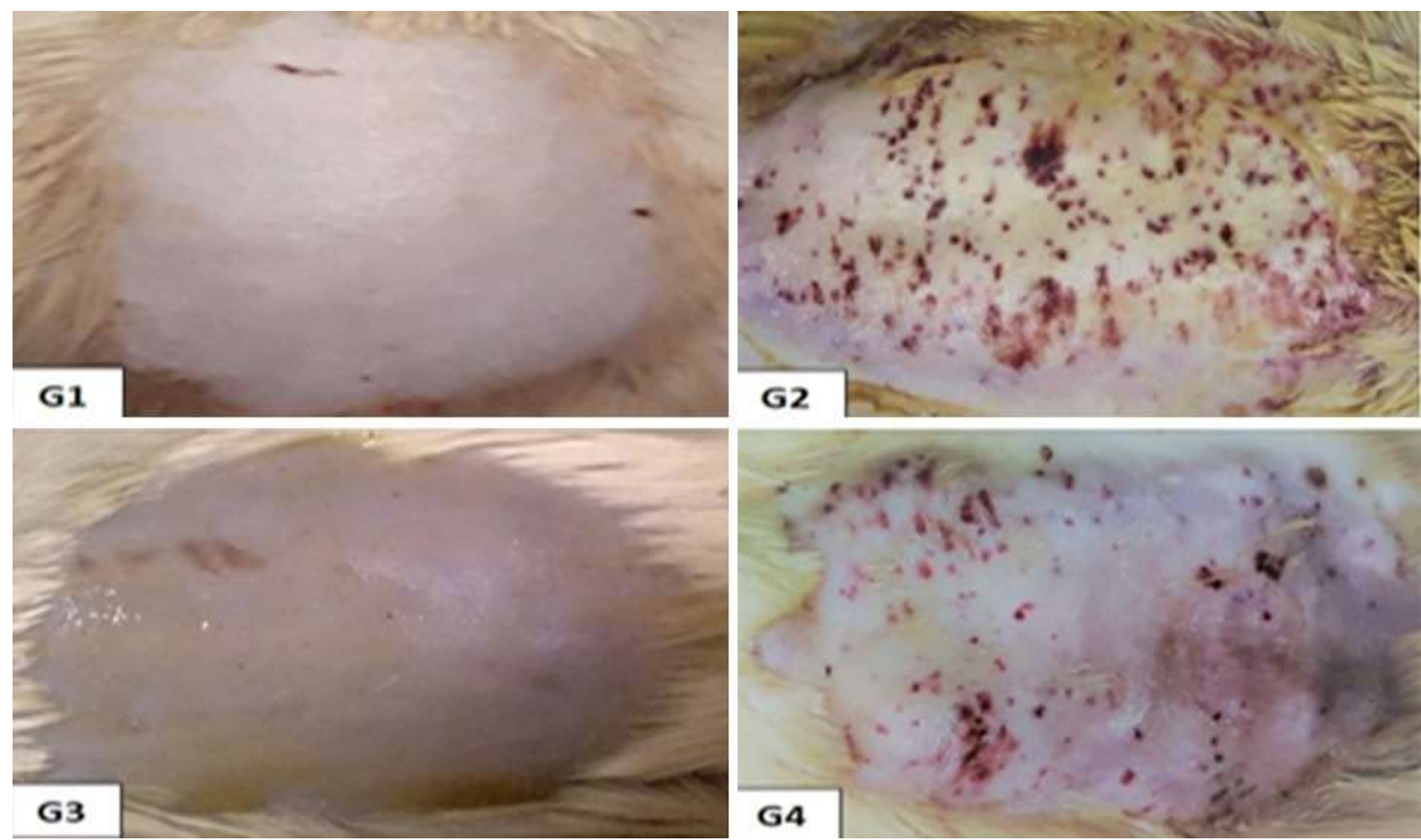

Source: Authors. 
Figure 4. Photomicrographs of the skin of hematoxylin and eosin stained Wistar rats in the different experimental groups. Skin not treated with photoprotective cream and not subjected to UVB irradiation (G1), skin subjected to UVB irradiation, (G2), skin subjected to the cream containing geopropolis and subjected to UVB irradiation (G3), skin was submitted to the application of the base cream and irradiated with UVB (G4). Note G1 and G3 skin with normal histological aspects. In G2 and G4 subepidermal blisters are present, besides necrotic cells, interstitial edema and collagen fiber dissociation. Obj. 20x. Scale bar $=200 \mu \mathrm{m}$.

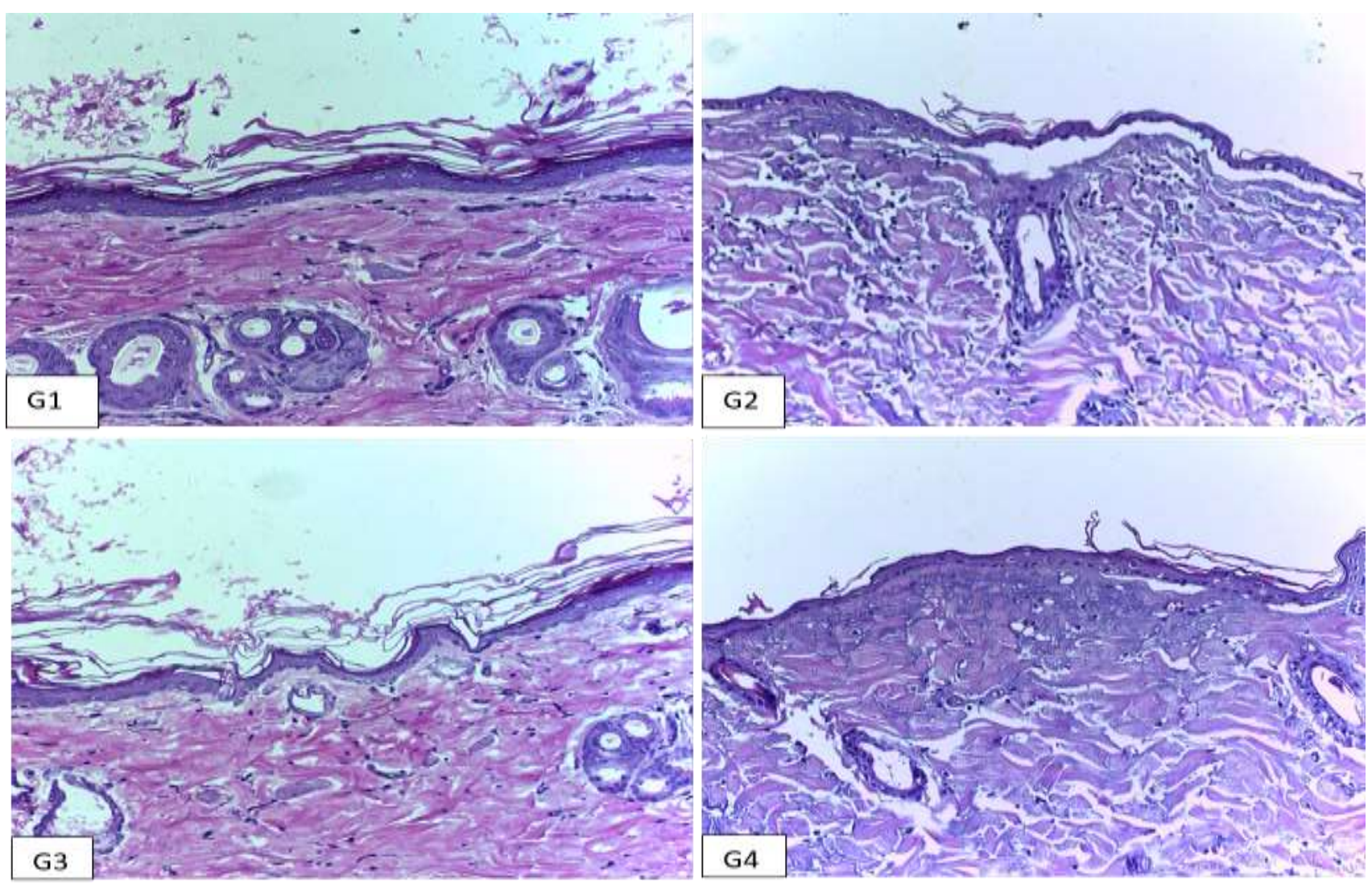

Source: Authors.

\section{Discussion}

\subsection{Chemical composition}

The evaluation using the HPLC-DAD-ESI-MS technique showed that HEG had a varied chemical composition, with 29 different types of phenolic compounds being detected, being 23 flavonoids and 5 phenols. High levels of phenolic compounds in HEG were found in this study according to the literature. Chemical studies of propolis of other stingless bees have been reported, such as Melipona fasciculata, Plebeia aff. flavocincta and Melipona mondury both products containing high contents of phenolic compounds (Batista et al., 2016; Santos et al., 2017; Silva et al., 2016). The various biological activities of propolis are attributed to high levels of phenolic compounds. The phenolic compounds exhibit a variety of biological actions, as they are considered good antioxidants, due to their ability to promote oxido-reduction, and neutralization of the reactive species of oxygen (Araújo et al., 2016).

The diversity of flavonoids, as verified in the geopropolis of the present study, may indicate high quality of the product because the presence and concentration of these compounds is used as a qualification index of propolis samples. Flavonoids represent one of the phenolic groups that have therapeutic properties with emphasis on antioxidant, antiinflammatory, vasodilator antibacterial, and healing potential (Testai, 2015; Vieira et al., 2008). 


\subsection{Antioxidant activity}

The antioxidant capacity of HEG was determined by the in vitro phototocolorimetric method DPPH, which is based on the ability of the extract's constituents to promote free radical reduction (DPPH). It was observed that the consumption of DPPH was directly proportional to the concentration of the sample and that there was a high antioxidant capacity of the extract in the concentrations of $1 \mathrm{mg} / \mathrm{mL}$ and $0.8 \mathrm{mg} / \mathrm{mL}$. A study showed that geopropolis, produced by meliponide Plebeia aff. flavocincta in the state of Rio Grande do Norte, Brazil, had high levels of total phenols and flavonoids, and high percentages of antioxidant activity, which reaches $95.65 \%$ ( Silva et al., 2016).

The antioxidant capacity of HEG was also evaluated using the IC50 value, which represents the amount of sample required to reduce the initial PPHD concentration by $50 \%$. IC50 below $50 \mu \mathrm{g} / \mathrm{mL}$ is considered very active. ${ }^{[31]}$ The lower the IC50 value, the greater the antioxidant capacity of the substance. Other species of the genus Melipona were also evaluated for antioxidant potential, in which low IC50 and high antioxidant activity were found. In the evaluation study of the antioxidant activity of four samples of geopropolis produced by Melipona fasciculata (Meliponinae) in the State of Maranhão, northeastern Brazil, was found values ranging from (4.24 $\mu \mathrm{g} \cdot \mathrm{mL}^{-1}$ to $44.24 \mu \mathrm{g} \cdot \mathrm{mL}^{-1}$ ) ( Silva et al., 2016).

The evidence of high antioxidant activity allows us to suggest that, in the same way as propolis produced by species of the genus Apis, geopropolis produced by native stingless bees, belonging to the group of Meliponines have a good potential as free radical scavengers. Thus, the potential for sequestering free radicals, evidenced by the low IC50, indication that geopropolis produced by Melipona subnitida has biological activity capable of exerting beneficial effects on the organism. Antioxidants act by eliminating free radicals protecting the cell membrane from the damaging action of reactive oxygen species (Pisoschi \& Pop, 2015). Therefore, the finding of geopropolis antioxidant activity opens new perspectives for its use in cosmetic formulations aiming to prevent or reverse the damage caused by free radicals.

\subsection{Cytotoxic activity}

In the present study, we evaluated the cytotoxic effect of HEG after incubation of fibroblasts (L929) and keratinocytes (HaCaT) with different concentrations of HEG for 72 hours using the MTT test. This test in order to estimate the cell survival rate after exposure to the test substance. The test is based on the ability of viable cell mitochondrial enzymes to convert the yellowish tretazolium salt (MTT) to formazan crystals which are purple in color. The amount of formazan formed is directly proportional to the number of viable cells, which can be quantified for color intensity by spectrophotometry and thus estimate cell viability (Porto et al., 2011).

The finding of no cytotoxic effect of HEG at concentrations of $1.25,0.65,3.12 ; 1.56$ and $0.78 \mu \mathrm{g} / \mathrm{mL}$ in L929 fibroblasts and $\mathrm{HaCaT}$ keratinocytes. These data show that there are no potentially toxic constituents in the extract and indicate safety in use. We emphasize that the cytotoxic effect of HEG was evaluated in two important cell lines that make up the integumentary system. Fibroblasts are the most common subcutaneous connective tissue cells, whose function is to synthesize extracellular matrix components such as: collagen fibers, reticular fibers and elastic fibers, in addition to producing growth factors that control proliferation and differentiation (Avery et al., 2018). Keratinocytes represent $80 \%$ of epidermal cells, whose main function is the synthesis of keratin, promote a barrier to skin protection (Wickett \& Visscher, 2006).

\subsection{Photoprotective activity}

The geopropolis produced by the bee Melipona subnitida from the semiarid region of Brazil had not been evaluated for photoprotective activity. Therefore, the sun protection factor of the base cream and of the cream containing geopropolis extract was evaluated in order to determine if the extract promotes SPF elevation of the formulation. When analyzing the SPF value of the base cream, which was $8.32 \pm 1.08$ and comparing it with the cream containing geopropolis extract, which was 
$20.13 \pm 1.27$, it was found that the addition of the geopropolis extract to the cream promoted the increase in the SPF value of the formulation. The potential photoprotector of propolis was also evaluated in a study by (Almeida et al., 2019). In this study, the authors verified that the incorporation of hydroalcoholic extract of Brazilian red propolis to the UVA-UVB photoprotector formulation, promoted the increase of the Solar Protection Factor (SPF) of the formulation.

The efficacy of the absorption capacity of radiant energy or photoprotective activity of a natural product is proportional to the amount of chromophore groups present in the extracts (Ribeiro et al., 2004). Natural products present in their composition active molecules that act as sunscreens, in which flavonoids and phenols stand out, which have the capacity to promote spectral absorption by solar radiation in the UVB range (Simões, 2007).

It is important to highlight that the cream containing geopropolis extract meets the quality requirements for a photoprotector. According to Brazilian legislation, a product to be registered as a photoprotector cosmetic must have an SPF higher than 6 (Brazil, Resolution $N^{\circ}$ 30. June 1, 2012). Therefore, the increase of SPF after incorporation of the geopropolis extract in the base cream shows promising potential for the use of geopropolis in cosmetic formulations with natural photoprotective activity, and can also be used as an adjunct to chemical filters, which would allow the reduction of the concentration of the latter in photoprotective formulations.

In the in vivo evaluation, it was evident that the cream containing hydroethanolic propolis extract was able to protect the irradiated skin with a UVB ultraviolet lamp, which emitted radiation in the range of 315-400 nm. No morphological changes were observed in the skin submitted to topical application of cream containing geopropolis extract and UVB irradiation, whereas in the skin submitted only to cream base and UVB irradiation, erythema and presence of blisters were observed.

Thus, the cream containing hydroethanolic geopropolis extract had a photoprotective effect, as it was able to protect the skin of Wistar rats from damage induced by UVB irradiation. The photoprotection mechanisms may be related to the high SPF and action of the cream containing geopropolis as effective barrier against UV radiation. The effectiveness of a natural or synthetic product as a sunscreen is defined as the ability to protect the skin against UV radiation burning. These products protect the skin by absorbing or reflecting and/or dispersing ultraviolet radiation preventing its damage (Melo \& Siqueira, 2012).

In addition, the cream containing geopropolis possibly acted as an antioxidant. In epidermis and dermis, UVB rays are absorbed by cellular chromophores that promote photochemical reactions and secondary interactions that generate free radicals, such as hydrogen peroxide, superoxide anion, among others, capable of promoting oxidative stress and consequently damage to DNA, proteins and membrane (Arimon et al., 2015; Romanhole et al., 2016). Since antioxidants have the ability to block the deleterious effects of free radicals, the photoprotective effect found in our research may therefore be associated with the antioxidant property of the tested geopropolis.

In HEG we detect 29 phenolic compounds, distributed between flavonoids and phenols. These compounds have remarkable antioxidant, anti-inflammatory, antibacterial and healing activities (Testai, 2015; Vieira et al., 2008). Inflammation is the acute response often observed in the skin after very intense exposure to UV radiation that damages the skin tissue leaving the skin reddened, sensitive and with the presence of blisters (Rhodes et al., 2009). Through the histological evaluation of the skin it is possible to suggest that geopropolis also had an anti-inflammatory effect, considering that in the skin of animals submitted to UVB irradiation there was the presence of high amount of polymorphonuclear inflammatory cells, mast cells, in addition to vascular congestion and interstitial edema, while in the skin of rats submitted to topical application of the cream containing geopropolis the histological pattern was similar to that of non-irradiated skin, used as a negative control. 


\section{Conclusion}

We concluded that the cream containing $10 \%$ of geopropolis extract produced by Melipona subnitida was able to protect the skin from the lesions induced by UVB irradiation, thus demonstrating a photoprotective effect. The results obtained can contribute to validate its use in topical formulations such as active sunscreens with the ability to protect the skin from damage caused by ultraviolet radiation.

Clinical studies in humans should be done to confirm the photoprotective effects of the geopropolis and guarantee its safe and effective use in future applications in sunscreens, adding value to this bee product, besides contributing to the sustainable use of natural products with application in the cosmetic industries and pharmaceutical companies.

\section{References}

Afrouzan, H., Tahghighi, A., Zakeri, S., \& Es-haghi, A. (2018). Chemical Composition and Antimicrobial Activities of Iranian Propolis. Iranian Biomedical Journal, 22(1). https://doi.org/10.22034/ibj.22.1.50

Akkol, E. K., Göger, F., Koşar, M., \& Başer, K. H. C. (2008). Phenolic composition and biological activities of Salvia halophila and Salvia virgata from Turkey. Food Chemistry, 108(3), 942-949. https://doi.org/10.1016/j.foodchem.2007.11.071

Almeida, W. A. S., Antunes, A. S., Penido, R. G., Correa, H. S. G., Nascimento, A. M. do, Andrade, Â. L., Santos, V. R., Cazati, T., Amparo, T. R., Souza, G. H. B. de, Freitas, K. M., Santos, O. D. H. dos, Sousa, L. R. D., \& Santos, V. M. R. dos. (2019). Photoprotective activity and increase of SPF in sunscreen formulation using lyophilized red propolis extracts from Alagoas. Revista Brasileira de Farmacognosia, 29(3), 373-380. https://doi.org/10.1016/j.bjp.2019.02.003

Araújo, K. S. S., Santos Júnior, J. F., Sato, M. O., Finco, F. D. B. A., Soares, I. M., Barbosa, R. S., Alvim, T. da C., Ascêncio, S. D., \& Mariano, S. M. B. (2016). Physicochemical properties and antioxidant capacity of propolis of stingless bees (Meliponinae) and Apisfrom two regions of Tocantins, Brazil. Acta Amazonica, 46(1), 61-68. https://doi.org/10.1590/1809-4392201501045

Arimon, M., Takeda, S., Post, K. L., Svirsky, S., Hyman, B. T., \& Berezovska, O. (2015). Oxidative stress and lipid peroxidation are upstream of amyloid pathology. Neurobiology of Disease, 84, 109-119. https://doi.org/10.1016/j.nbd.2015.06.013

Avery, D., Govindaraju, P., Jacob, M., Todd, L., Monslow, J., \& Puré, E. (2018). Extracellular matrix directs phenotypic heterogeneity of activated fibroblasts. Matrix Biology, 67, 90-106. https://doi.org/10.1016/j.matbio.2017.12.003

Baillo, V. P., \& Lima, A. C. (2012). Nanotecnologia aplicada à fotoproteção. Revista Brasileira de Farmácia, 93(3), 271-278.

Batista, C. M., Alves, A. V. F., Queiroz, L. A., Lima, B. S., Filho, R. N. P., Araújo, A. A. S., Albuquerque Júnior, R. L. C., \& Cardoso, J. C. (2018). The photoprotective and anti-inflammatory activity of red propolis extract in rats. Journal of Photochemistry and Photobiology B: Biology, 180, 198-207. https://doi.org/10.1016/j.jphotobiol.2018.01.028

Batista, M. C. A., Abreu, B. V. de B., Dutra, R. P., Cunha, M. S., Amaral, F. M. M. do, Torres, L. M. B., \& Ribeiro, M. N. de S. (2016). Chemical composition and antioxidant activity of geopropolis produced by Melipona fasciculata (Meliponinae) in flooded fields and cerrado areas of Maranhão State, northeastern Brazil. Acta Amazonica, 46(3), 315-322. https://doi.org/10.1590/1809-4392201600034

Brazil, Resolução № 30, de $1^{\circ}$ de Junho de 2012. Aprova o Regulamento Técnico Mercosul sobre Protetores Solares em Cosméticos e dá outras providências., no. 30, Diretoria Colegiada da Agência Nacional de Vigilância Sanitária (2012). http://bvsms.saude.gov.br/bvs/saudelegis/ anvisa/2012/rdc0030_01_06_2012.html

Cabral, L. D. S., Pereira, S. O., \& Partata, A. K. (2011). Filtros solares e fotoprotetores mais utilizados nas formulações no Brasil. Revista Científica Do ITPAC, 4(3), 1-10.

Cardinault, N., Cayeux, M. O., \& Percie du Sert, P. (2012). La propolis: Origine, composition et propriétés. Phytothérapie, 10(5), 298-304. https://doi.org/10.1007/s10298-012-0733-y

Carvalho-Zilse, G. A., \& Silva, C. G. N. (2012). Threats to the Stingless Bees in the brazilian Amazon: How to deal with scarce biological data and an increasing rate of destruction. Nova Science Publishers, 147-168.

Castro, R. N., \& Salgueiro, F. B. (2016). Comparação entre a composição química e capacidade antioxidante de diferentes extratos de própolis verde. Química Nova, 39(10), 1192-1199. https://doi.org/10.21577/0100-4042.20160136

Figueiredo, S. A., Vilela, F. M. P., Silva, C. A., Cunha, T. M., Santos, M. H., \& Fonseca, M. J. V. (2014). In vitro and in vivo photoprotective/photochemopreventive potential of Garcinia brasiliensis epicarp extract. Journal of Photochemistry and Photobiology B: Biology, 131, 65-73. https://doi.org/10.1016/j.jphotobiol.2014.01.004

Garcia, R. C., Sá, M. E. P., Langoni, H., \& Funari, S. R. C. (2004). Efeito do extrato alcoólico de própolis sobre a Pasteurella multocida "in vitro" e em coelhos. Acta Scientiarum. Animal Sciences, 26(1), 69-77. https://doi.org/10.4025/actascianimsci.v26i1.1952

Hatami, T., Emami, S. A., Miraghaee, S. S., \& Mojarrab, M. (2014). Total Phenolic Contents and Antioxidant Activities of Different Extracts and Fractions from the Aerial Parts of Artemisia biennis Willd. Iranian Journal of Pharmaceutical Research: IJPR, 13(2), 551-559. 
Karapetsas, A., Voulgaridou, G. P., Konialis, M., Tsochantaridis, I., Kynigopoulos, S., Lambropoulou, M., Stavropoulou, M.-I., Stathopoulou, K., Aligiannis, N., Bozidis, P., Goussia, A., Gardikis, K., Panayiotidis, M. I., \& Pappa, A. (2019). Propolis Extracts Inhibit UV-Induced Photodamage in Human Experimental In Vitro Skin Models. Antioxidants, 8(5), 125. https://doi.org/10.3390/antiox8050125

Kranjc, E., Albreht, A., Vovk, I., Makuc, D., \& Plavec, J. (2016). Non-targeted chromatographic analyses of cuticular wax flavonoids from Physalis alkekengi L. Journal of Chromatography A, 1437, 95-106. https://doi.org/10.1016/j.chroma.2016.01.061

Kunrath, C. A., Savoldi, D. C., Mileski, J. P. F., Novello, C. R., Alfaro, A. da T., Marchi, J. F., \& Tonial, I. B. (2017). Application and evaluation of propolis, the natural antioxidant in Italian-type salami. Brazilian Journal of Food Technology, 20. https://doi.org/10.1590/1981-6723.3516

Mansur, J. S., Breder, M. N. R., Mansur, M. C. A., \& Azulay, R. D. (1986). Determination of sun protection factor by spectrophotometry. An. bras. dermatol, $61,121-124$.

Melo, M. R., \& Siqueira, A. P. N. D. F. (2012). Desenvolvimento de uma loção fotoprotetora, avaliação da estabilidade e determinação in vitro do FPS. Perquirere, 9(1), 81-97.

Mensor, L. L., Menezes, F. S., Leitão, G. G., Reis, A. S., Santos, T. C., Coube, C. S., \& Leitão, S. G. (2001). Screening of Brazilian plant extracts for antioxidant activity by the use of DPPH free radical method: antioxidant activity in Brazilian plants. Phytotherapy Research, 15(2), 127-130. https://doi.org/10.1002/ptr.687

Mosmann, T. (1983). Rapid colorimetric assay for cellular growth and survival: application to proliferation and cytotoxicity assays. Journal of Immunological Methods, 65(1-2), 55-63. https://doi.org/10.1016/0022-1759(83)90303-4

Pontes, M. L. C., Vasconcelos, I. R. A., Diniz, M. F. F.M., \& Pessôa, H. D. L. F. (2018). Chemical characterization and pharmacological action of Brazilian red propolis. Acta Brasiliensis, 2(1), 34. https://doi.org/10.22571/2526-433868

Porto, I. C. C. M., Oliveira, D. C., Raele, R. A., Ribas, K. H. S., Montes, M. A. J. R., \& Castro, C. M. M. B. (2011). Cytotoxicity of current adhesive systems: In vitro testing on cell cultures of primary murine macrophages. Dental Materials, 27(3), 221-228. https://doi.org/10.1016/j.dental.2010.10.006

Rhodes, L. E., Gledhill, K., Masoodi, M., Haylett, A. K., Brownrigg, M., Thody, A. J., Tobin, D. J., \& Nicolaou, A. (2009). The sunburn response in human skin is characterized by sequential eicosanoid profiles that may mediate its early and late phases. The FASEB Journal, 23(11), 3947-3956. https://doi.org/10.1096/fj.09-136077

Ribeiro, R. P., Santos, V. M., Medeiros, E. D., Silva, V. A., Volpato, N. M., \& Garcia, S. (2004). Avaliação do fator de proteção solar (FPS) in vitro de produtos comerciais e em fase de desenvolvimento. Pharm Bras, 16(1), 86-88.

Romanhole, R. C., Ataide, J. A., Cefali, L. C., Moriel, P., \& Mazzola, P. G. (2016). Photostability study of commercial sunscreens submitted to artificial UV irradiation and/or fluorescent radiation. Journal of Photochemistry and Photobiology B: Biology, 162, 45-49. https://doi.org/10.1016/j.jphotobiol.2016.06.011

Saewan, N., \& Jimtaisong, A. (2013). Photoprotection of natural flavonoids. Journal of Applied Pharmaceutical Science. https://doi.org/10.7324/JAPS.2013.3923

Santos, T. L. A. D., Queiroz, R. F., Sawaya, A. C. H. F., Lopez, B. G.-C., Soares, M. B. P., Bezerra, D. P., Rodrigues, A. C. B. C., Paula, V. F. D., \& Waldschmidt, A. M. (2017). Melipona mondury produces a geopropolis with antioxidant, antibacterial and antiproliferative activities. Anais Da Academia Brasileira de Ciências, 89(3 suppl), 2247-2259. https://doi.org/10.1590/0001-3765201720160725

Sforcin, J. M., \& Bankova, V. (2011). Propolis: Is there a potential for the development of new drugs? Journal of Ethnopharmacology, 133(2), 253-260. https://doi.org/10.1016/j.jep.2010.10.032

Silva, C. C. F., Salatino, A., Motta, L. B., Negri, G., \& Salatino, M. L. F. (2019). Chemical characterization, antioxidant and anti-HIV activities of a Brazilian propolis from Ceará state. Revista Brasileira de Farmacognosia, 29(3), 309-318. https://doi.org/10.1016/j.bjp.2019.04.001

Silva, J. B., Costa, K. M. F. M., Coelho, W. A. C., Paiva, K. A. R., Costa, G. A. V., Salatino, A., Freitas, C. I. A., \& Bati sta, J. S. (2016). Quantificação de fenóis, flavonoides totais e atividades farmacológicas de geoprópolis de Plebeia aff. flavocincta do Rio Grande do Norte. Pesquisa Veterinária Brasileira, 36(9), 874-880. https://doi.org/10.1590/s0100-736x2016000900014

Simões, C. M. O. (2007). Farmacognosia: da planta ao medicamento. Editora da UFSC; Editora da UFRGS.

Testai, L. (2015). Flavonoids and mitochondrial pharmacology: a new paradigm for cardioprotection. Life Sciences, 135, 68-76. https://doi.org/10.1016/j.lfs.2015.04.017

Vieira, A. P., Santos, N. R., Borges, J. H. S., Vincenzi, M. P. A., \& Schmitz, W. O. (2008). Flavonoid action in second intention healing in surgically-induced clean wounds in Wistar rats. Semina: Ciências Biológicas e Da Saúde, 29(1), 65. https://doi.org/10.5433/1679-0367.2008v29n1p65

Wickett, R. R., \& Visscher, M. O. (2006). Structure and function of the epidermal barrier. American Journal of Infection Control, 34(10), S98-S110. https://doi.org/10.1016/j.ajic.2006.05.295 